\title{
System analysis and the problem field of digitalization in the system of the agro-industrial complex
}

\author{
Alla Rasputina* \\ Baikal state University, Irkutsk, Russia
}

\begin{abstract}
In the context of a global market, the agro-industrial complex (AIC) system is undergoing continuous modernization in order to respond effectively to market challenges. The project of digitalization of agriculture has a clear character of modernization. It can be assumed that this project of the Ministry of agriculture is based on an optimistic scenario (unconditional implementation of the presented quantitative indicators within the specified time frame).

The purpose of the study is to evaluate the efficiency of applying expert assessment methods to the problem of digitalization in the agro-industrial complex system. Using the methods of system analysis and, first of all, various methods of expert assessment, cognitive analysis and modeling, as well as scenario development, the weak points of the optimistic scenario of the departmental project were identified and the algorithms of the realistic scenario were determined. A review of scientific publications that reflect the problems of digitalization of agriculture, based mainly on the positions of system analysis. It is based on scientific publications in journals included in the Russian science citation index system, as well as in journals included in international scientometric databases, such as Scopus and Web of Science. The author presents the structure of problems in tabular and graphical form using methods of cognitive analysis and hierarchy analysis. The result was shown two schemes that reflect the structure of socioeconomic, technological and reengineering blocks in the agricultural sector, de-fining the basic contours of the problem field of digitization, as well as the graph structure of the problem field of digitalization of agriculture, showing the interconnection and interaction of individual structural components.
\end{abstract}

\section{Introduction}

In the process of macroeconomic modeling, agro-industrial complex systems in most cases are based on the structure of production functions and relationships. And in essence they are engaged in modeling the technical and technological subsystem of the agro-industrial complex.

We believe that the system of the agro-industrial complex belongs to complex heterogeneous systems and includes three subsystems that have a different nature and operate

\footnotetext{
* Corresponding author: rasp77@mail.ru
} 
on the basis of different laws: economic, technical, environmental and social. As a rule, the operation of these laws manifests itself in the form of even more complex interpenetrating intersystem formations: socio-technical, socio-economic, ecological-economic, technicaltechnological, natural-technical.

In the context of the global market, competition is sharply increasing and the system of the agro-industrial complex is moving into a stage of constant modernization in order to effectively respond to market challenges. It is a process with many unknowns and variables.

As N. Wiener argued, "the market is a game and it is strictly subordinated to the general theory of games. Even with two players, the theory of the game is complicated... And with many players, in the vast majority of cases, the results of the game are characterized by extreme uncertainty and instability. There is no homeostasis here. We should go through boom and bust cycles in business life" [1, p. 15].

Accordingly, in a complex environment in which the object of our research is located the system of the agro-industrial complex of Russia - only such a synthetic interdisciplinary technology of scientific research as system analysis allows the synthesis of all knowledge about the object of study, which is a complex system, and obtain more adequate knowledge and models, necessary for practical application.

Systems analysis is a complex process that uses the latest achievements of the humanities, mathematical and heuristic research methods to achieve the set goals. System analysis acts as a tool for integrating diverse research, is implemented pursuant to the scheme from the stages of applying informal methods through the stages of formal and again to informal methods [2].

The Departmental Project "Digital Agriculture" [3], which has a pronounced character of modernization, was taken as a starting point for the study.

The purpose of the study is to assess the applicability of the methods of expert analysis to the problem of digitalization of agriculture (the most urgent problem of the entire agroindustrial complex system currently). It is necessary to assess the problem field of digitalization from the standpoint of the synthesis of different points of view of experts (in our case, scientists considering the most diverse aspects of the problem).

We believe that this project can be considered the basis of an optimistic digitalization scenario, since there is no internal assessment of critical moments in it, and the scenario figures indicate its unconditional implementation within the specified time frame. We assume to study how this optimistic scenario corresponds to the realistic scenario in several stages. Therefore, at the first stage of the study, we will consider the key points of the pessimistic scenario of digitalization of agriculture, relying on the methods of expert assessments, cognitive analysis and modeling, and methods for developing scenarios.

By the problem field of digitalization of agriculture, we mean a set of problems that exist in the modeled object and in the environment in their relationship with each other.

The number of scientific publications on the problems of digitalization of agriculture that have appeared over the past three years is already measured in hundreds. A review of such a significant amount of material seems redundant. We stopped at several dozen, making a selection pursuant to the principle of significance for the upcoming modeling and the formation of a problem field - a semi-structured (at the first stage) set of problems and tasks of different ranks and different levels of hierarchy.

First, we will consider several important points reflected in the departmental project "Digital Agriculture". The main objectives of this optimistic scenario are formulated as follows:

- increase in labor productivity at agricultural enterprises by 2 times per employee (by 2024);

- reduction of the unit costs of enterprises for business administration by 1.5 times; 
- reducing the share of material costs in the cost of a unit of agricultural products (fuels and lubricants, fertilizers, electricity, planting material, feed, etc.) by $20 \%$ or more [3].

Virtually none of the publications dispute the attainability of the above benchmarks or indicators of successful project implementation. As, however, the ways of achieving such results and their consequences are not analyzed.

Moreover, it is assumed that by 2024 all regions of Russia will successfully implement digital sectoral planning of agricultural production, despite very significant differences in the starting positions of all regions. For instance, if we compare the initial level of digitalization of agriculture in the Krasnodar Territory and the Republic of Tuva, we immediately notice a significant difference in the starting positions of the regions. Moreover, we have not yet come across publications reflecting the existing differentiation in the level of digitalization of the agro-industrial complex in Russian regions.

One more fragment of the departmental project should be cited in full, since it will be essential for our study and for building a pessimistic scenario: "We should not allow a delay in the development and adoption of normative legal acts, on which the normative regulation and legislative consolidation of the project depends, as well as acts providing for subsidies for agricultural producers in connection with the large number of involved federal executive bodies and complex lengthy procedures for coordinating the submitted subsidies" [3].

In our opinion, the developers of the project with this fragment designate one of the events of the project, which can significantly affect the implementation of the optimistic scenario. This is also noted by A.A. Darkov: "Solving problems in the field of digital technologies application is impossible without creating an efficient legal regulation mechanism ... The level of legal regulation of the digitalization of agriculture requires significant modernization" [4].

A number of authors, considering the problems of agriculture digitalization technology, pay special attention to the formation of the ecosystem of the digital economy, noting the relevance of creating an environment that provides conditions for the innovative development and distribution of digital services, products, devices and applications [5-12].

The need to stimulate innovation processes in the agro-industrial complex and the decisive importance of accelerating the innovation process is noted by [13-23]. A special place, in our opinion, is occupied by works related to the methodology and practice of scenario forecasting [24-25].

In addition, a key role in the digitalization process is played by the development and integration of GIS with other information resources with subsequent synchronous and optimal use [26-28].

A hard-to-review block of work, as a rule, concerns all sorts of aspects of modeling various processes in the agro-industrial complex system, and we used some of them in this work when constructing the problem field of digitalization of agriculture. We also drew attention to the rarity of publications on the problem of probable futuroshock that can occur among the rural population as a result of the digitalization of agriculture, and which has been studied for a long time in various countries of the world. [29-39].

\section{Methods}

The research methodology is based on the selective application of system analysis methods aimed at studying complex objects of the agro-industrial complex system, with the predominant use of expert assessment methods.

We consider it expedient to resort to informal methods of analysis when solving difficult problems, because by no means every task of analyzing a system during its design can be accurately formulated mathematically. The meaning of informal or heuristic procedures is formalization. 
Informal methods of systems analysis mobilize the intuition and experience of specialists and are constructively used in the organization of analytical activities [2, 40-43].

We equate the situation with the digitalization project in the Russian agro-industrial complex system to a large-scale reengineering project of the industry (if not the entire agroindustrial complex system). Reengineering is the use of the latest information technology to achieve completely new business goals. The challenge of reengineering is to fundamentally rethink and radically redesign existing processes to deliver leaps and bounds.

In addition to the methods of expert assessments in the entire wide range, we consider it expedient to use methods of scenario forecasting, as well as methods of cognitive analysis and modeling, which we propose to implement at the next stages of the study.

As we noted above, the departmental project for the digitalization of agriculture [3] is perceived by us as an optimistic scenario focused on the unconditional implementation of the project and the achievement of the results and indicators declared in the project. More precisely, it can be formulated that it is a conceptual optimistic scenario in which there is no strictly logical and qualitative justification for successive steps to move towards the goal, expressed in the corresponding network schedule of the target implementation of the project. As well as the lack of various model characteristics of the conceptual scenario, for which it is necessary to do a thorough work on scenario modeling. It is possible that some important stages in the scenario modeling of achieving the project goals were carried out by the project developers, but they are not reflected in this departmental project. Therefore, there is a need to develop a technical scenario for the implementation of both the entire departmental project and its constituent structural and functional elements.

To reflect the reliable conditions of the project implementation process, it is desirable to use a minimax approach, which in this case is expressed in the development of three scenarios: optimistic, pessimistic and realistic, which ultimately is the final technical product for innovative implementation in the agro-industrial complex.

To obtain realistic results, it is necessary, whenever possible, to abandon the facilitating assumptions in our models and to accept difficult situations as they are.

It is convenient to describe complex objects and phenomena in the context of expert analysis and cognitive modeling in the form of a simple set of elements and connections between them.

Graph theory provides a simple, affordable and powerful tool for building models and solving problems of ordering objects. By means of the mathematical apparatus of the graph theory, many cognitive-semantic functions of the investigated operations are effectively displayed. In addition to the language of graph theory, object ordering problems can be formulated in terms of matrix theory with zero-one elements, or in finite set theory. In some cases, it is advisable to use the mathematical apparatus of fuzzy logic, as well as the Markov scheme, which is conveniently represented in the form of an oriented graph on a plane (for probabilistic modeling of real evolutionary processes). But since the author's main task is to search for structural algorithms that reflect the qualitative features of a real complex system, it is advisable at the first stage of the work to maximize the use of the hierarchy analysis method focused on maximum decomposition in order to identify a set of the simplest algorithms combined into a whole algorithmic system. Without completing a sufficiently complete cycle of decomposition and identifying the qualitative structures of a real complex system, we consider it premature to reflect the system analysis process in strict mathematical expressions, because this stage of the study is predominantly heuristic, and not strictly logical and formal. Premature formalization most often leads to an unreliable reflection of the real properties of the system under study.

To graphically construct the problematic field of digitalization, we used the Edraw Mind Map program. To build a structure graph - Microsoft Excel 2016. 


\section{Results of the study}

In the course of the first stage of the study, based on a certain sample of expert publications on the state of problems in the agro-industrial complex in the context of the digitalization project, we formulated a sample set of problems that form the basis of the pessimistic scenario of the digitalization of agriculture. The problems that determine the basis of the pessimistic scenario are presented in the table. Potential negative consequences due to unresolved problems are reflected in the column "Consequences", in the column "Possible solutions" - a general definition of a solution to the problem. This allows to develop a way to solve the problem in the process of implementing a digitalization project.

Table 1. The main problems in the agro-industrial complex system in the context of digitalization (expert assessments)

\begin{tabular}{|c|c|c|c|c|}
\hline № & Definition & Content & Consequences & $\begin{array}{c}\text { Possible } \\
\text { solutions }\end{array}$ \\
\hline 1 & $\begin{array}{l}\text { Low level of } \\
\text { innovation }\end{array}$ & $\begin{array}{l}\text { Deterioration of } \\
\text { machine and } \\
\text { tractor fleet, lag in } \\
\mathrm{R} \& \mathrm{D} \text {, lack of } \\
\text { domestic robotics, } \\
\text { lack of an efficient } \\
\text { system of } \\
\text { innovation }\end{array}$ & $\begin{array}{l}\text { Low technical and } \\
\text { technological level of } \\
\text { production }\end{array}$ & $\begin{array}{l}\text { The need to intensify } \\
\text { R\&D, technology } \\
\text { parks and innovation } \\
\text { centers }\end{array}$ \\
\hline 2 & $\begin{array}{l}\text { Bipolarity of the } \\
\text { agricultural } \\
\text { economy (high } \\
\text { and low profitable } \\
\text { farms) }\end{array}$ & $\begin{array}{c}\text { Large and } \\
\text { medium-sized } \\
\text { enterprises - } 36.5 \\
\text { thousand, small } \\
\text { forms of economy } \\
-136.7 \text { thousand. }\end{array}$ & $\begin{array}{l}\text { High probability of } \\
\text { non-participation in } \\
\text { digitalization of many } \\
\text { small forms of } \\
\text { economy }\end{array}$ & $\begin{array}{l}\text { Advance creation of } \\
\text { regional clusters } \\
\text { uniting farmers and } \\
\text { private household } \\
\text { plots }\end{array}$ \\
\hline 3 & $\begin{array}{l}\text { Poor elaboration } \\
\text { of digitalization } \\
\text { scenarios }\end{array}$ & $\begin{array}{l}\text { The departmental } \\
\text { project "Digital } \\
\text { Agriculture" } \\
\text { considers only the } \\
\text { optimistic scenario }\end{array}$ & $\begin{array}{l}\text { In case of deviation } \\
\text { from the parameters of } \\
\text { the optimistic scenario, } \\
\text { the project will be } \\
\text { implemented locally }\end{array}$ & $\begin{array}{l}\text { Develop pessimistic } \\
\text { and realistic scenarios }\end{array}$ \\
\hline 4 & $\begin{array}{c}\text { Clear lack of IT } \\
\text { specialists }\end{array}$ & $\begin{array}{l}\text { To support the } \\
\text { digitalization } \\
\text { project, an } \\
\text { additional 90-100 } \\
\text { thousand IT } \\
\text { specialists }\end{array}$ & $\begin{array}{c}\text { Disruption of } \\
\text { quantitative and } \\
\text { qualitative parameters } \\
\text { dramatically reduces } \\
\text { the full-fledged } \\
\text { implementation of the } \\
\text { project } \\
\end{array}$ & $\begin{array}{l}\text { State order for the } \\
\text { training of IT } \\
\text { specialists in the } \\
\text { system of agricultural } \\
\text { and technical } \\
\text { universities }\end{array}$ \\
\hline 5 & $\begin{array}{l}\text { Low profitability } \\
\text { of agricultural } \\
\text { production due to } \\
\text { rent-seeking by } \\
\text { processors, } \\
\text { intermediaries and } \\
\text { service enterprises }\end{array}$ & $\begin{array}{l}\text { Loans, long } \\
\text { supply chains take } \\
\text { up to } 95 \% \text { of } \\
\text { margin }\end{array}$ & $\begin{array}{l}\text { In the process of } \\
\text { implementing a } \\
\text { digitalization project, } \\
\text { the losses of small } \\
\text { forms of economy can } \\
\text { be from } 70 \text { to } 90 \%\end{array}$ & $\begin{array}{l}\text { Creation of regional } \\
\text { clusters uniting } \\
\text { farmers and private } \\
\text { household plots }\end{array}$ \\
\hline 6 & $\begin{array}{l}\text { Lack of legal } \\
\text { regulation of } \\
\text { agricultural } \\
\text { digitalization } \\
\text { processes }\end{array}$ & $\begin{array}{l}\text { Determines the } \\
\text { speed and } \\
\text { guarantee of } \\
\text { innovation and } \\
\text { business processes }\end{array}$ & $\begin{array}{l}\text { In case of non- } \\
\text { regulation of legal } \\
\text { support - disruption of } \\
\text { the implementation of } \\
\text { various components of } \\
\text { the project }\end{array}$ & $\begin{array}{c}\text { Advanced } \\
\text { development of acts } \\
\text { of legal support and } \\
\text { regulation }\end{array}$ \\
\hline
\end{tabular}


Continuation of Table 1.

\begin{tabular}{|c|c|c|c|c|}
\hline 7 & $\begin{array}{l}\text { Lack of an } \\
\text { efficient system } \\
\text { for forecasting } \\
\text { and neutralizing } \\
\text { risks, including } \\
\text { agricultural } \\
\text { insurance }\end{array}$ & $\begin{array}{l}\text { Reduces the } \\
\text { mobility and } \\
\text { efficiency of } \\
\text { agricultural } \\
\text { production }\end{array}$ & $\begin{array}{l}\text { The risk of financial } \\
\text { and other losses and } \\
\text { losses increases sharply }\end{array}$ & $\begin{array}{l}\text { Creation and } \\
\text { optimization of } \\
\text { regional centers for } \\
\text { forecasting and risk } \\
\text { management }\end{array}$ \\
\hline 8 & $\begin{array}{l}\text { Lack of } \\
\text { development of } \\
\text { the social } \\
\text { consequences of } \\
\text { digitalization in } \\
\text { agriculture } \\
\end{array}$ & $\begin{array}{l}\text { The most sensitive } \\
\text { and responsive } \\
\text { component of } \\
\text { agricultural } \\
\text { production }\end{array}$ & $\begin{array}{l}\text { Inflicting significant } \\
\text { damage to the human } \\
\text { factor of agriculture }\end{array}$ & $\begin{array}{c}\text { Taking social } \\
\text { consequences into } \\
\text { account when } \\
\text { developing a realistic } \\
\text { digitalization scenario }\end{array}$ \\
\hline 9 & $\begin{array}{l}\text { Weak level of } \\
\text { expert advisory } \\
\text { service for } \\
\text { agriculture }\end{array}$ & $\begin{array}{l}\text { In the process of } \\
\text { implementing a } \\
\text { digitalization } \\
\text { project, the role of } \\
\text { experts and } \\
\text { consultants } \\
\text { increases } \\
\text { dramatically }\end{array}$ & $\begin{array}{l}\text { In the absence of well- } \\
\text { coordinated and } \\
\text { efficient work of } \\
\text { experts and consultants, } \\
\text { the efficiency of the } \\
\text { reengineering process } \\
\text { sharply decreases }\end{array}$ & $\begin{array}{l}\text { Creation of a unified } \\
\text { federal system of } \\
\text { support, control and } \\
\text { monitoring of the } \\
\text { expert and consulting } \\
\text { service }\end{array}$ \\
\hline 10 & $\begin{array}{l}\text { Low level of } \\
\text { monitoring of the } \\
\text { natural, technical } \\
\text { and social } \\
\text { environment }\end{array}$ & $\begin{array}{l}\text { Increasing risks } \\
\text { and losses in all } \\
\text { areas of the } \\
\text { agricultural } \\
\text { digitalization } \\
\text { project } \\
\end{array}$ & $\begin{array}{c}\text { In the absence of a } \\
\text { high-quality monitoring } \\
\text { system for all areas of } \\
\text { agriculture, the } \\
\text { feasibility of the project } \\
\text { is below } 50 \%\end{array}$ & $\begin{array}{l}\text { Integration of } \\
\text { monitoring resources } \\
\text { and implementation } \\
\text { of optimal } \\
\text { technologies }\end{array}$ \\
\hline
\end{tabular}

Note: compiled by the author.

In addition, on the basis of expert publications, two block diagrams were developed (Fig. 1 and Fig. 2), reflecting the main contours of the problem of the digitalization field in the agro-industrial complex system, conditionally divided into a socio-economic and technological block (Fig. 1) and an information and reengineering block (Fig. 2). In reality, the agro-industrial complex and in the digitalization project itself, the two designated blocks work in close interaction and intertwining, but nevertheless retain their characteristics and mechanisms of action due to their systemic nature (social, economic, informational, technological, reengineering). 


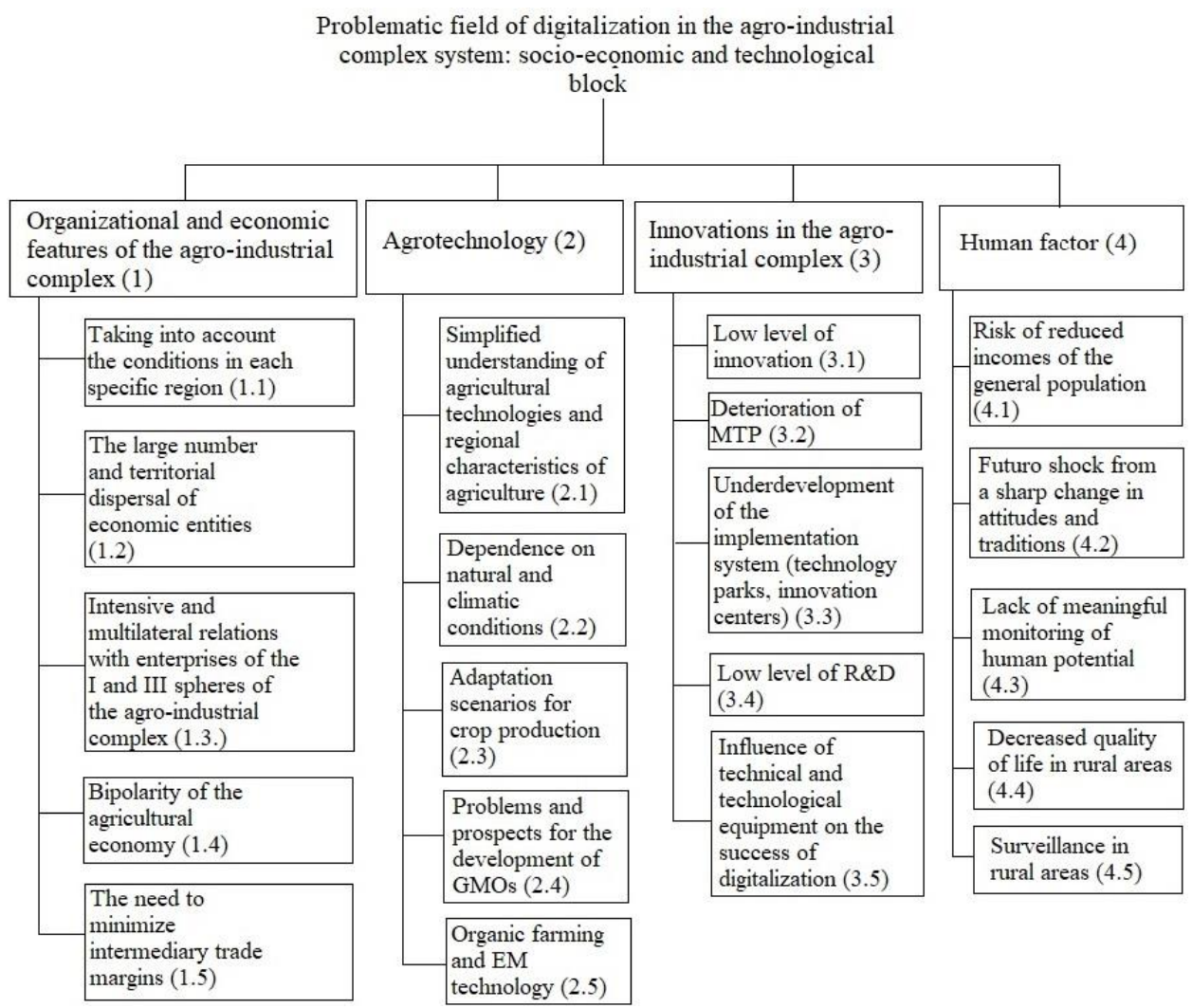

Fig. 1. Block diagram A of the problem field of digitalization in the agro-industrial complex system: socio-economic and technological block.

Note: compiled by the author. 
Problematic field of digitalization in the agro-industrial complex system: information and reengineering block

\begin{tabular}{|l|}
\hline Digitalization (5) \\
\hline $\begin{array}{l}\text { Digital security } \\
(5.1)\end{array}$ \\
\hline $\begin{array}{l}\text { Weak current } \\
\text { level of } \\
\text { digitalization } \\
(5.2)\end{array}$ \\
\hline $\begin{array}{l}\text { Digital } \\
\text { Industry } \\
\text { Ecosystem } \\
(5.3)\end{array}$ \\
\hline $\begin{array}{l}\text { Integration of } \\
\text { information } \\
\text { resources (5.4) }\end{array}$ \\
\hline $\begin{array}{l}\text { An integrated } \\
\text { approach to } \\
\text { digitalization policy } \\
(5.5)\end{array}$ \\
\hline
\end{tabular}

\begin{tabular}{l} 
Planning, modeling, \\
forecasting (6) \\
\begin{tabular}{|l|}
\hline Macroeconomic \\
Models and \\
Forecasting (6.1)
\end{tabular} \\
\hline $\begin{array}{l}\text { The danger of } \\
\text { projecting world } \\
\text { experience on the } \\
\text { agro-industrial } \\
\text { complex of the } \\
\text { Russian Federation } \\
\text { (other criteria) } \\
\text { (6.2) }\end{array}$ \\
\begin{tabular}{|l|} 
Risk management \\
system (6.3)
\end{tabular} \\
\hline $\begin{array}{l}\text { Adequacy of } \\
\text { models in the AIC } \\
\text { system and real } \\
\text { applied value (6.4) }\end{array}$ \\
\begin{tabular}{|l} 
The presence of \\
scenarios of \\
optimistic, \\
pessimistic and \\
realistic \\
development (6.5)
\end{tabular} \\
\hline
\end{tabular}

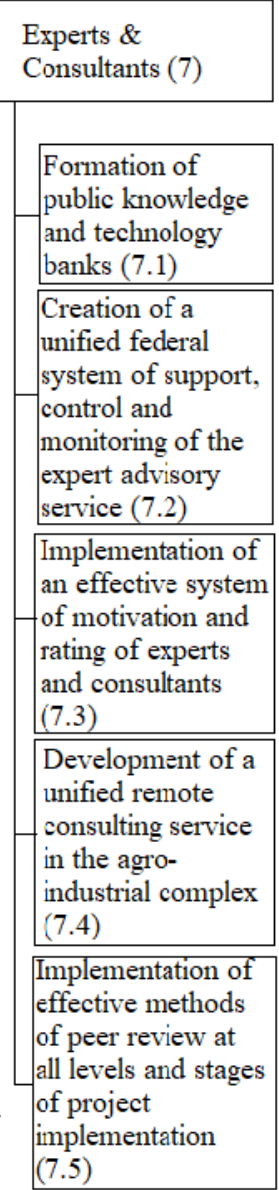

\begin{tabular}{|l|}
\hline $\begin{array}{l}\text { IT Technology } \\
\text { Training (8) }\end{array}$ \\
\hline $\begin{array}{l}\text { Real analysis of } \\
\text { starting } \\
\text { opportunities (for } \\
1000 \text { people } \\
\text { working in the } \\
\text { agro-industrial } \\
\text { complex - 1 IT } \\
\text { specialist) (8.1) }\end{array}$ \\
\hline $\begin{array}{l}\text { Creation and } \\
\text { efficiency of work } \\
\text { of } 54 \text { centers of } \\
\text { competence at } \\
\text { agricultural } \\
\text { universities ( } 8.2)\end{array}$ \\
\hline $\begin{array}{l}\text { The need to train } \\
\text { at least } 90 \\
\text { thousand IT } \\
\text { specialists for the } \\
\text { agro-industrial } \\
\text { complex in } 2-3 \\
\text { years ( } 8.3 \text { ) }\end{array}$ \\
\hline $\begin{array}{l}\text { To retrain } 50 \% \text { of } \\
\text { specialists in the } \\
\text { salt sector for the } \\
\text { digital economy } \\
\text { (8.4) }\end{array}$ \\
\begin{tabular}{|l} 
The problem of \\
ensuring the quality \\
of training and \\
retraining of \\
specialists ( 8.5$)$
\end{tabular} \\
\hline
\end{tabular}

Fig. 2: Block diagram B of the problematic field of digitalization in the agro-industrial complex system: information and reengineering block.

Note: compiled by the author.

In Fig. 3 shows a graph of the structure of the problem field of digitalization of agriculture, which reflects the interconnections and interactions of individual structural components, which it is advisable to subject to further expert assessment, in order to determine the significance of each interaction within the agro-industrial complex system and the degree of its influence on the successful implementation of the digitalization project. 


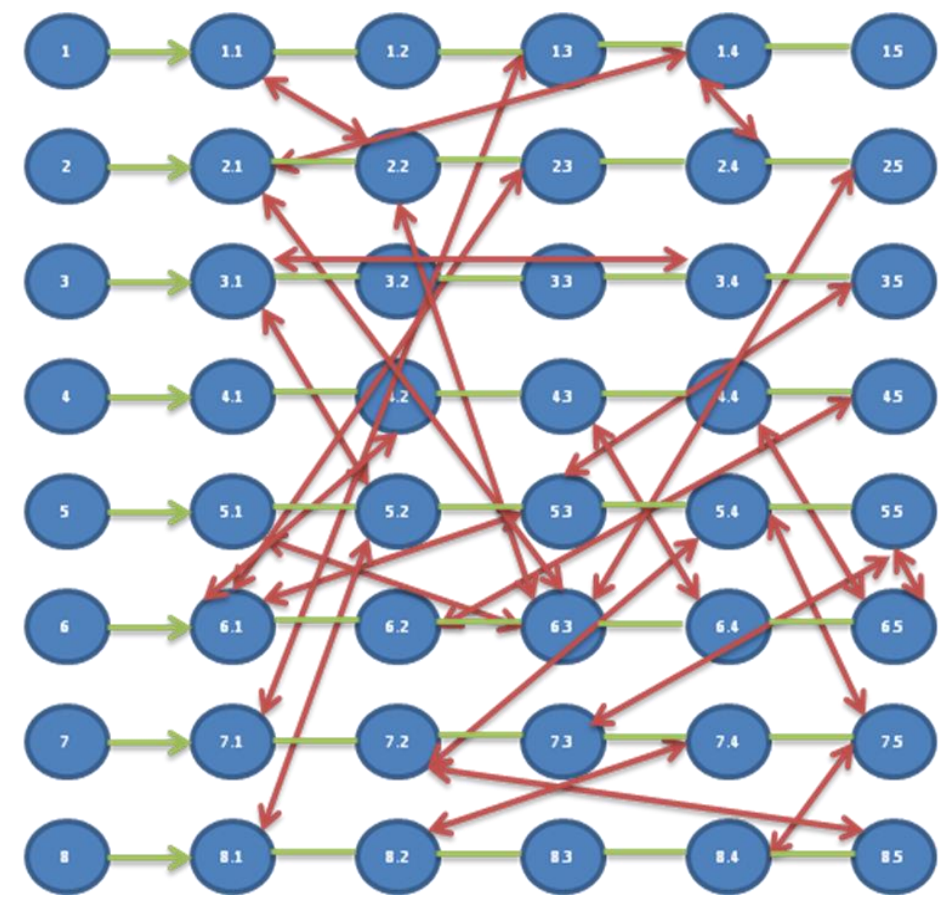

Fig. 3. Graph of the structure of the problem field of digitalization in the AIC system (block A and block B).

Note: compiled by the author.

The list of problems given in the table "Main problems in the agro-industrial complex system in the context of digitalization (expert assessments)" is not complete. In addition to those research authors whom we consider experts and who are presented in the bibliography for this publication (see links in the text), we also used the judgments of agricultural experts with whom we repeatedly communicated during the research. This stage, which includes selective publications of researchers and discussions with expert experts, along with the study of other special literature, is called passive examination in the practice of peer review and analysis.

The table "Main problems ..." is mainly intended for use in the development of a pessimistic scenario and is not a complete prototype of the block diagrams shown in Fig. 1 and Fig. 2.

In turn, Fig. 3 is a digraph completely based on block diagrams A and B (Figs. 1 and 2), and is displayed by us as a conceptual basis for the development of a realistic version of the scenario, convenient for subsequent expert-analytical and cognitive-modeling work at the second stage of the study using methods of active and detailed examination of each structural and functional element, presented in block diagrams A and B (Fig. 1 and Fig. 2), and, accordingly, in the digraph of the structure of the problem field (Fig. 3).

At the stage of heuristic and conceptual modeling, such qualitative operations are widespread in systems analysis, a kind of which is (as well as a constituent element) expert analysis.

\section{Discussion of the results}

The problem field of digitalization of agriculture obtained as a result of our research, expressed in tabular and graphical form, is a prototype of a cognitive map, convenient for 
further use when working with experts in the agro-industrial complex. Using the methods of peer review, two digitalization scenarios will be developed: pessimistic and realistic. The algorithms of the above scenarios (especially for the weak points of the optimistic scenario) can be of practical importance for use in the decision-making process on a digitalization project at all hierarchical levels of management in the agro-industrial complex system.

\section{Conclusions}

The departmental rural digitalization project is based on an optimistic scenario and assumes the unconditional implementation of the presented indicators. Despite the presence of weaknesses (lagging behind the legal framework, ignoring possible negative social consequences and an extremely weak level of innovation in the agro-industrial complex), the project as a whole can be implemented. An increase in labor productivity at agricultural enterprises by 2 times per worker (by 2024) can be achieved through a sharp reduction (bankruptcy and takeover) of farms and medium-sized enterprises, which will lead to further degradation of rural settlements, redistribution of land resources in benefit of large holdings, increased unemployment in rural areas and other negative consequences. To avoid unforeseen and undesirable results, there is an urgent need to mobilize expert and advisory resources and capabilities in the agro-industrial complex system to create pessimistic and realistic scenarios, as well as scientifically grounded algorithms for making managerial decisions, considering the dynamic diversity of internal and external factors in the agroindustrial complex system.

The active use of the entire range of methods for expert assessment of predicted and simulated situations, the use of cognitive analysis and modeling in the development and implementation of a scenario for the digitalization of agriculture can be of decisive importance in this process.

There is a need for the active use of expert assessment methods when discussing a departmental project for the digitalization of agriculture. This will identify weaknesses or critical paths in the optimistic scenario presented by the Ministry of Agriculture.

There is an urgent need to develop pessimistic and realistic scenarios for the digitalization of agriculture, which will create more flexible conditions for the efficient implementation of the project.

When constructing digitalization scenarios, it is necessary to use a variety of expert assessment methods, including cognitive analysis and modeling, which will make the algorithms for management decisions applicable at different levels of management in the agro-industrial complex system.

The results of the research can be used for a radical renewal of the expert advisory service in the agro-industrial complex system.

\section{References}

1. N. Viner, Kibernetika, ili upravleniye i svyaz' v zhivotnom i mashine, 215 (1958)

2. A.P. Sukhodolov, V.A. Marenko, Sistemnyy analiz, modelirovaniye. Matematicheskoye modelirovaniye, 144 (2018)

3. Vedomstvennyy proyekt «Tsifrovoye sel'skoye khozyaystvo», 48 (2019)

4. A.A. Darkov, Gosudarstvennaya sluzhba i kadry 1, 26 (2019). doi.org/10.24411/23120444-2019-10003

5. Yu.E. Vashukevich, Ya.M. Ivagno, Baikal Research J. 4, 58 (2010) 
6. T. I. Gayrabekova, Vestnik Astrakhanskogo gosudarstvennogo tekhnicheskogo universiteta. Seriya: Upravleniye, vychislitel'naya tekhnika i informatika 1, 165 (2012)

7. YU. M. Akatkin, O. E. Karpov, V. A. Konyavskiy, Ye. D. Yasinovskaya, Biznesinformatika 4,17 (2017)

8. T. N. Astakhova, M. O. Kolbanev, A. A. Shamin, Vestnik Nizhegorodskogo gosudarstvennogo inzhenerno-ekonomicheskogo universiteta 6 (85), 5 (2018)

9. A. N. Semin, M. M. Kislitskiy, I. YU. Agnayeva, V. YU. Vorona, ETAP 6, 73 (2018)

10. S. M. Kurbatova, L. YU. Aysner, Agrarnoye i zemel'noye pravo 4 (172), 102 (2019)

11. YA. M. Ivan'o, Ekstremal'nyye prirodnyye yavleniya: metodologiya, modelirovaniye $i$ prognozirovaniye, 267 (2007)

12. A. P. Sukhodolov, A. P. Fedotov, P. N. Anoshko, A. V. Kolesnikova, P. G. Sorokina, N. V. Mamonova, Vserossiyskiy kriminologicheskiy zhurnal 14(1), 76 (2020) https://doi.org/10.17150/2500- 4255.2020.14(1)

13. A.P. Sukhodolov, A.P. Fedotov, M.M. Makarov, P.N. Anoshko, P.G. Sorokina, A.V. Kolesnikova, D.A. Zhabina, Bulletin of Baikal State University 30(2), 233 (2020) https://doi.org/10.17150/2500- 2759.2020.30(2).233-244

14. A. Kh. Gelyakhova, S.B. Dzobelov, Terra Economicus 1-3, 72 (2010)

15. V. N. Ovchinnikov, M. V. Arshba, Terra Economicus 11(3-3), 5 (2013)

16. V. I. Loyko, N. V. Yefanova, Politematicheskiy setevoy elektronnyy nauchnyy zhurnal Kubanskogo gosudarstvennogo agrarnogo universiteta 113, 1001 (2015)

17. V. N. Kurochkin, M. V. Grechko, Vestnik agrarnoy nauki Dona 1(37), 25 (2017)

18. L. M. Kornilova, Ye. A. Ivanov, P. A. Ivanov, Innovatsionnoye razvitiye ekonomiki 5(47), 52 (2018)

19. Z. Ye. Shaporova, N. V. Titovskaya, Nauka i obrazovaniye: opyt, problemy, perspektivy razvitiya, 96 (2018)

20. E. Khitrova, T. Khitrova, AEBMR-Advances in Economics Business and Management Research 81,312 (2019). doi.org/10.2991/mtde-19.2019.59

21. A. Rasputina, N. Zhilkina, S. Ovanesyan, V. Tyunkov, Advances in Economics, Business and Management Research 01, 113 (2020) https://doi.org/10.2991/fred19.2020 .74

22. A. V. Rasputina, O. Yu. Ziboreva, AEBMR-Advances in Economics Business and Management Research 81, 331 (2019).

23. S. S. Ovanesyan, Baikal Research Journal 6(6), 4 (2015) https://doi.org/10.17150/24116262.2015.6(6).4

24. N. A. Medvedeva, Metodologiya stsenarnogo prognozirovaniya razvitiya sel'skogo khozyaystva regionov Yevropeyskogo Severa RF: dis. ... d-ra ekon. nauk, 350 (2016)

25. N. A. Medvedeva, Molochnokhozyaystvennyy vestnik 3(23), 100 (2016)

26. D. YU. Samygin, N. G. Baryshnikov, L. A. Mizyurkina, Ekonomika regiona 3, 865 (2019) https://doi.org/10.17059/2019-3-18

27. T. I. Pis'man, I. YU. Pugachova, Ye. YU. Zhukova, A. P. Shevyrnogov, Matematicheskaya model' sezonnoy dinamiki agrofitotsenozov s uchetom nazemnykh i sputnikovykh izmereniy. Doklady Akademii nauk, 428(6), 841 (2009)

28. M. L. Vartanova, Ye. V. Drobot, Ekonomicheskiye otnosheniya 8(1), 1 (2018)

29. V. V. Vershinin, T. N. Kovaleva, M. M. Demidova, P. P. Lebedev, Moskovskiy ekonomicheskiy zhurnal 5(1), 16 (2018). doi.org/10.24411/2413-046X-2018-15008 
30. M. S. Krass, V. G. Merzlikin, O. V. Sidorov, Vestnik Tomskogo gosudarstvennogo universiteta 350, 200 (2011)

31. Ye. V. Lutsenko, V. I. Loyko, T. P. Baranovskaya, Politematicheskiy setevoy elektronnyy nauchnyy zhurnal Kubanskogo gosudarstvennogo agrarnogo universiteta 83, 695 (2012)

32. O. V. Kozhevina, Izvestiya Altayskogo gosudarstvennogo universiteta 1-1(77), 148 (2013)

33. O. I. Pavlushkina, Kontseptsiya razrabotki modeli struktury upravleniya sotsial'noekonomicheskim razvitiyem sel'skogo khozyaystva Rossii v usloviyakh global'nykh protsessov. Materialy Ostrovskikh chteniy, 106 (2015)

34. A. S. Khukhrin, Modelirovaniye agrarnykh klasterov: mul'tidistsiplinarnyy podkhod. Natsional'naya assotsiatsiya uchenykh (NAU) 3(19),116 (2016)

35. A. N. Tyrsin, A. A. Surina, Vestnik Tomskogo gosudarstvennogo universiteta. Upravleniye, vychislitel'naya tekhnika i informatika 39, 65 (2017)

36. I. A. Romanenko, N. Ye. Yevdokimova, Innovatsionnyye, informatsionnyye i kommunikatsionnyye tekhnologii 1,132 (2018)

37. A. A. Aytpayeva, Vestnik Astrakhanskogo gosudarstvennogo tekhnicheskogo universiteta. Seriya: Ekonomika 3, 56 (2019)

38. N. A. Gviliya, A. V. Parfonov, T. G. Shul'zhenko, Upravlenets 10(1), 40 (2019)

39. Y. Ivanyo, P. Asalkhanov, N. Bendik, Management of the Agro-Industrial Enterprise: Optimization Uncertainty Expert Assessments. International Multi-Conference on Industrial Engineering and Modern Technologies, 1 (2019). doi.org/10.1109/FarEastCon.2019.8934788

40. A. Nechaev, A. Rasputina, Integrated depreciation management system. IOP Conference Series: Earth and Environmental Science 421, 32011 (2020). doi.org/10.1088/17551315/421/3/032011.

41. E. V. Loshchenko, P. M. Dashkevich, L. V. Kazantsev, System Analysis \& Mathematical Modeling 2(1), 54 (2020)

42. Ye. A. Skvortsov, Ye. G. Skvortsova, I. S. Sandu, G. A. Iovlev, Ekonomika regiona 14(3), 1014 (2018)

43. Ye. P. Chirkov, Vestnik FGOU VPO Bryanskaya GSKHA 5, 59 (2014)

44. I. A. Shpekht, R. R. Saakyan, Sostoyaniye metodov i podkhodov sistemnogo analiza v sovremennykh usloviyakh. Nauchnoye naslediye F. A. Shcherbiny: sbornik materialov XVIII mezhdunarodnoy nauchno-prakticheskoy konferentsii, 236 (2018) 